\title{
Identification and analysis of difficulties in the implementation of HACCP in Russian food industry enterprises
}

\author{
Elena Chernova ${ }^{1, *}$, Irina Bazhenova $^{1}$, Larisa Tsupranova $^{2}$, Valeria Bychenkov $a^{1}$, and Tatiana Bazhenova ${ }^{3}$ \\ ${ }^{1}$ Graduate School of Biotechnology and Food Production, Peter the Great St. Petersburg Polytechnic University, St. Petersburg, Russia \\ ${ }^{2}$ St. Petersburg State Autonomous Professional Image Institution «Naval Technical College named after Admiral DN Senyavin», St. \\ Petersburg, Russia \\ ${ }^{3}$ Institute of secondary vocational education. Peter the Great St.Petersburg Polytechnic University (SPbPU), St. Petersburg, Russia
}

\begin{abstract}
The article shows the difficulties and risks that arise when implementing the HACCP system in Russian enterprises of the food industry. An expert group of specialists of different profiles and competencies identified the risks using the brainstorming method. An analysis of the risks that arise during the development and implementation of a food safety system based on the principles of HACCP showed that according to the source of occurrence, they are divided into two groups: external and internal. External risks include the risks posed by the state, which, according to experts, are the most significant. These include: poor educational work; lack of explanatory materials on the preparation and implementation of the system; lack of harmonization of HACCP requirements with the regulatory framework of the Russian Federation; complex terminology, complex presentation of information, etc. Internal risks include risks from the management and personnel of catering enterprises: a formal approach to the creation and implementation of the system, a low level of education for linear personnel, an imperfect incentive system, non-compliance with discipline in maintaining records and documents of the system, etc. The article describes actions to minimize the identified types of risks.
\end{abstract}

\section{Introduction}

Since February 15, 2015, all enterprises of the Russian Federation that manufacture food products, including enterprises of the food industry, are obliged to carry out their activities in accordance with the requirements of HACCP [1, Article 10, paragraph 2]. Despite the fact that more than four years have passed, most public catering enterprises, especially small and medium ones, continue to experience difficulties in developing and implementing a food safety management system (hereinafter - the FSMS). It is required to note that manufacturers in different countries are experiencing difficulties in implementing the FSMS. At the same time, various aspects of the problem are distinguished: financial, technical, managerial, organizational, educational, psychological ones.

Many researchers believe that all the difficulties in the implementation of the FSMS are related to a lack of understanding or ignorance of the principles of implementation of HACCP [2-4]. In Taiwan, a study was conducted on the relationship between knowledge in the field of food safety and the practical use of HACCP system by restaurant workers. A correlation was established between theoretical knowledge and the practice of HACCP [5]. It is shown that great attention should be paid to teaching the principles of HACCP to managers of enterprises [6]. Lack of support from the leadership and commitment of employees [3, 7-9], overly complex documentation of the system [10] are called the main barriers in the work of the FSMS. Lack of time, frequent staff changes, lack of staff motivation, complicated terminology and inadequate staff training are also obstacles for the successful implementation of HACCP [4].

Many researchers note difficulties encountered in the implementation of various principles of HACCP: during the identification and assessment of hazards, during the preparation of technological schemes [10]. There is an indication of the lack of clear logic in determining critical control points when working with the decision tree [11].

In addition to identifying problems and developing actions to address them, researchers are improving approaches to the analysis of the various principles of HACCP. Thus, Ryu Kyung Park introduced a new analytical method that uses beta and triangular probability distributions to improve the hazard stage analysis. The model they developed calculates the level of risk depending on the likelihood of a particular hazard [12].

Russian scientists are exploring the problems of introducing HACCP [13, 14], the possibility of increasing automation [15] and the use of express methods of quality and safety control in catering facilities [16], but they do not conduct risk analysis.

\footnotetext{
* Corresponding author: chernova68@list.ru
} 
However, the identification of risks arising from the development and implementation of a food safety system is a prerequisite for making informed management decisions. This enhances the ability to achieve the goals of the organization.

According to the theory of risk management, it is required to manage it when there is a need to make complex decisions, at the stages of product development or when studying the feasibility of making changes [10]. In the new version of the ISO 22000 standard of the 2018 edition, the concept of risk-oriented thinking is integrated. The standard recommends organizations to apply a new type of thinking in all processes. Preventive measures become part of the system in the planning, implementation, analysis and evaluation, i.e. throughout the Plan-Do-Check-Act (PDCA) cycle. Therefore, the identification and study of risks that occur during the creation, implementation and implementation of the FSMS provides the opportunity to make informed decisions and competently manage processes and events in the organization.

The aim of the study is to identify the risks arising from the construction, implementation and implementation of FSMS in the food industry of the Russian Federation.

\section{Methods of research}

The study used methods of analysis and brainstorming. To conduct a "brainstorming" a group of specialists from different profiles was formed. The joint creative activity of experts, each has his own experience, vision of the situation and knowledge, forms a synergistic effect, greatly enhancing the result of the search for solutions [17, p. 80-82]. The organization of the "brainstorming" was carried out in accordance with the requirements: clearly formulated problem, objectives, object, subject of study, selection, systematization and evaluation of ideas. The studies were conducted in June 2017 and September 2019. In 2017, the expert group consisted of 8 people, in 2019 - of 7 people. The group of experts included the heads of catering enterprises, a medical doctor, a specialist in certification of management systems, cooks, and college and university teachers.

\section{Research results}

Risks arising from the development, implementation and operation of the food safety system at the food industry enterprises can be classified depending on the reason for their occurrence. These are risks emanating from the state, management and personnel of enterprises, which are logically divided into two large groups: external and internal (table 1).
Table 1. Risks arising from the development, implementation and functioning of the FSMS in the enterprises of the food industry of the Russian Federation.

\begin{tabular}{|c|c|c|}
\hline \multirow{2}{*}{$\begin{array}{c}\text { External source of } \\
\text { risk from } \\
\text { government } \\
\end{array}$} & \multicolumn{2}{|c|}{ Internal Sources of Risk } \\
\hline & $\begin{array}{c}\text { from the management } \\
\text { of the enterprise }\end{array}$ & $\begin{array}{c}\text { by line } \\
\text { personnel }\end{array}$ \\
\hline $\begin{array}{l}\text { Weak educational } \\
\text { work by the state, } \\
\text { lack of explanatory } \\
\text { materials on the } \\
\text { preparation and } \\
\text { implementation of } \\
\text { the system }\end{array}$ & $\begin{array}{l}\text { Lack of understanding } \\
\text { on the part of } \\
\text { management of food } \\
\text { enterprises of the } \\
\text { strategy and tactics of } \\
\text { creating a food safety } \\
\text { system HACCP }\end{array}$ & $\begin{array}{l}\text { Inadequate } \\
\text { staff } \\
\text { education }\end{array}$ \\
\hline $\begin{array}{l}\text { Lack of } \\
\text { harmonization of } \\
\text { HACCP } \\
\text { requirements with } \\
\text { the regulatory } \\
\text { framework of the } \\
\text { Russian Federation }\end{array}$ & $\begin{array}{l}\text { Formal approach to the } \\
\text { creation and } \\
\text { implementation of the } \\
\text { system }\end{array}$ & $\begin{array}{l}\text { Low } \\
\text { motivation }\end{array}$ \\
\hline $\begin{array}{c}\text { Complex } \\
\text { terminology, } \\
\text { complex } \\
\text { presentation of } \\
\text { information } \\
\end{array}$ & $\begin{array}{l}\text { Insufficient resources } \\
\text { allocated for the } \\
\text { implementation and } \\
\text { operation of the FSMS }\end{array}$ & $\begin{array}{l}\text { Low } \\
\text { discipline }\end{array}$ \\
\hline $\begin{array}{l}\text { Lack of standard } \\
\text { methods for the } \\
\text { creation and } \\
\text { implementation of } \\
\text { the HACCP food } \\
\text { safety system }\end{array}$ & $\begin{array}{l}\text { Inadequate work with } \\
\text { external suppliers of } \\
\text { products and services }\end{array}$ & $\begin{array}{l}\text { Incomplete } \\
\text { compliance } \\
\text { with } \\
\text { instructions } \\
\text { of the } \\
\text { HACCP } \\
\text { system } \\
\end{array}$ \\
\hline $\begin{array}{l}\text { Lack of adaptation } \\
\text { of the system to }\end{array}$ & \multicolumn{2}{|c|}{$\begin{array}{l}\text { Imperfection of incentive system for } \\
\text { management and line personnel }\end{array}$} \\
\hline enterprises & \multicolumn{2}{|c|}{ Food Safety Awareness } \\
\hline
\end{tabular}

When the authors of the article talk about external risks emanating from the state, they appeal to such government agencies as the Rospotrebnadzor Regional Offices of the Russian Federation and scientific organizations Scientific Research Institutes, which are part of the Federal Service for Surveillance on Consumer Rights Protection and Human Wellbeing. In order to minimize this type of risk, it is necessary to carry out active educational activities and organize training in the basics of HACCP not in the form of courses held at the bases of various commercial centers and organizations, but with the involvement of specialists from Rospotrebnadzor and on the basis of scientific organizations included in the structure of the mentioned Federal Service. Most of the current courses and programs on HACCP are not supported by the state. 80 $\%$ of the training time for such programs is devoted to theoretical issues, and only $20 \%$ to the practice of the system and the development of its documentation. There is a need to create a network of demonstration small and medium-sized public catering enterprises, where the FSMS successfully operates. In the Russian Federation, such a form of support for small business as business incubators has been developed. They can also be used to train and help create a product safety system based on the principles of HACCP. 
Analysis of professional periodical paper materials for the period between July 1, 2013, when TR TS 021/2011 was put into effect, and February 15, 2015, when food-producing enterprises were supposed to implement the HACCP system, shows that the transition period was not used at all to inform interested people. Any publications on food safety systems began to appear in Russian professional journals only in the spring of 2015. The experience of foreign countries shows that to disseminate information on the creation and implementation of the HACCP security system, not only professional, but also other means of mass communication were used to present the materials of both theoretical and practical nature. The Codex Alimentarius CAC / RCP 1-1969 (2003 version), a document that provides guidance on the application of the HACCP system, clearly states that "... training representatives of industry, government and academies on the principles and application of HACCP, raising awareness Consumers are essential elements for the effective implementation of the system ... Work instructions and procedures must be developed ... It is necessary to provide opportunities for joint training of industry and government representatives in order to encourage and maintain a long dialogue, and to create an atmosphere of understanding in the practical implementation of the HACCP system" [18]. However, these recommendations in the Russian Federation were not fully implemented. In our opinion, the state has not created a methodological and training base, limited to controlling functions. The absence of standard instructions and the methodology of the HACCP system leads to a significant increase in the time required to develop documentation and difficulties in implementing the HACCP system. Therefore, many food business executives see the HACCP system as a burdensome and formal obligation imposed by the state.

Organization of assistance is especially important for small businesses and individual entrepreneurs, whose share in the Russian Federation accounts for more than $60 \%$ of the total turnover of public catering enterprises $[19$, p. 490]. It should be understood that in order to create, implement and maintain a security system, the management and personnel of catering enterprises must have knowledge, skills and abilities in such areas as:

- food sanitation and hygiene,

- technology for the production of catering products,

- organization of production and services,

- quality and safety management,

- regulatory, technical and technological support of production, etc.

In most cases, in small catering establishments of employees with all of the listed competencies, it is not enough. Consequently, the risks posed by the imperfection of state instruments for implementing the HACCP system are the most dangerous.

The second most important risk group comes from the leaders of food enterprises. These include:

- lack of understanding of food industry specialists and responsibility in the implementation of the FSMS;

- lack of understanding of how to combine the sanitary rules in force in the Russian Federation and the requirements of HACCP in a single system (provided that good hygiene practice is the basic condition for the successful implementation of the principles of HACCP $[20,21])$;

- a formal approach to the development and implementation of the FSMS;

- lack of understanding that documented monitoring of all stages of production allows you to resolve conflicts, reduce the amount of advertising, material losses and increase consumer confidence.

In addition, the top and middle managers must carry out continuous and systematic monitoring of the operation of the HACCP system.

The risks associated with the work of the staff at first glance seem insignificant, but their underestimation can destroy even a functioning security system. Work with personnel should be carried out in several directions: training, improving production and hygiene discipline, developing motivational programs, introducing modern forms of incentives.

The creation and implementation of the FSMS is recommended to be carried out jointly with employees. This allows two goals - to create a HACCP system and train employees to work with it.

Experts noted that the reluctance of staff to conduct daily work with records and documents of the HACCP system, which are not complicated, but require organization, methodology, punctuality, leads to the fact that the FSMS turns into a huge number of inoperative documents. Therefore, continuous staff training, demonstration of the results of the HACCP system will provide both an understanding of the goals of this activity and increase motivation for further improvement of the system.

The main risk associated with the managers and personnel of enterprises is that the HACCP system may turn into a package of inoperative documents and cease to bring real benefits. In this case, the trust of all interested parties is reduced, the level of food safety and the stability of the organization are violated.

Part of the risks arising in the Russian food industry enterprises during the development, implementation and operation of the HACCP food safety system are also realized in other countries, i.e. do not have national features. This lack of understanding of the principles of HACCP implementation, absence of motivation and support from the management, unsufficiently trained personnel, sophisticated terminology. In the Russian Federation, risks specific to our country are also being realized: the lack of harmonization of the requirements of the HACCP with the regulatory framework of the Russian Federation; lack of standard practices for the creation and implementation of a system of food safety HACCP.

\section{Conclusions}

Analysis of the risks inherent in the development and implementation of food safety system based on HACCP principles, showed that sources of occurrence are divided into two groups: external and internal. External group 
includes the risk of the state: weak educational work, the lack of clear and accessible educational methodologies to develop and implement FSMS and others. Internal risks include those emanating from the management and personnel of catering enterprises: a formal approach to creating and implementing a system, a low level of education for line personnel, an imperfection of the incentive system, non-observance of discipline in maintaining records and documents of the system, etc. The article considers actions to minimize these types of risks. It is proposed to intensify educational activities on food safety with the involvement of not only professional publications, but other media. Organize training in the basics of HACCP with experts Rospotrebnadzor and on the basis of scientific organizations within the structure of the Federal Service for Supervision in the Sphere of protection of the rights of consumers and well-being of a person. To compile a list of small and medium-sized catering enterprises in which the FSMS successfully operates. Demonstrate and disseminate their work experience. Develop model guidelines and the HACCP methodology. Directly and regularly conduct training of personnel in the field of food safety in enterprises, improve production and hygienic disciplines, develop motivational programs and implement modern forms of stimulation.

The authors also note the identified risks that are realized only in the Russian Federation (for example, the lack of harmonization of HACCP requirements with the regulatory framework of the Russian Federation), and interstate risks (lack of understanding of the principles of HACCP implementation, lack of employee motivation and support from management, lack of training of personnel, the complex terminology, and others.).

\section{References}

[1] TR TS 021/2011, O bezopasnosti pishchevoj produkcii, Tekhnicheskij reglament Tamozhennogo soyuza (2011).

[2] Y. Motarjemi, H. Lelieveld (Eds.), Food safety management. A practical guide for the food industry, Academic Press, London, 845-872 (2014).

[3] C.A. Wallace, W.H. Sperber, S.E. Mortimore, Food safety for the 21st century. Managing HACCP and food safety throughout the global supply chain, Wiley, Oxford, Second edition (2018).

[4] M. Baş, M. Yüksel, T. Çavuşoğlu, Turkey Food Cont., 18, 2 (2007).

[5] Wen-Hwa Ko, Food Cont., 29, 1 (2013).

[6] J.E. Ehiri, G.P. Morris, J. McEwen, Food Cont., 6, 6 (1995).

[7] E. Chen, S. Flint, P. Perry, M. Perry, R Lau, Food Cont., 47 (2015).

[8] S. Gilling, E.A. Taylor, K. Kane, J.Z. Taylor, J Food Prot., 64, 5 (2001).
[9] K. Milios, E.Z. Pantelis, A.M. Pantouvakis, H.D. Mataragas, British Food J, 115, 9 (2013).

[10] W. Dzwolak, Food Cont., 106 (2019).

[11] M. Bertolini, M. Bevilacqua, A. Rizzi, J Food Eng., 79, 4 (2007).

[12] Kyung Ryu, Ki-Hwan Park, Ji-Young Yang, Gyung-Jin Bahk, Food Cont., 30, 2 (2013).

[13] L.Z. Gabdukaeva, O.A. Reshetnik, A.M. Fajzulin, Vestnik tekhnologicheskogo universiteta, 18, 21 (2015).

[14] E.V. Chernova, M.D. Gushchina, Zdorovoe pitanie s rozhdeniya: medicina, obrazovanie, pishchevye tekhnologii, IX Rossijskij Forum, 8082 (2014)

[15] E. Chernova, V. Bychenkova, N. Kotova, K. Pupykin, IOP Conf. Ser.: Mater. Sci. Eng., 497, 012108 (2019).

[16] G. Alexseev, A. Khripov, S. Eliseeva, A. Smolentceva, IOP Conf. Ser.: Mater. Sci. Eng., 497, 1, 012105 (2019).

[17] M.A. Gershman, Innovacionnyj menedzhment, Moskva, Market DS (2010).

[18] CAC/RCP 1-1969, Rev. 4-2003, Recommended International code of practice general principles of food hygiene, Rossijskij statisticheskij ezhegodnik, Moskva, Rosstat (2016).

[19] G. Grintzali, F. Babatsikou, Health Sc. J., 4, 2 (2010).

[20] D.Z. Mcswane, R. Linton, J. Environmental health, 62, 6 (2000). 